\title{
Pandangan Dunia Pengarang Dalam Novel Putri Karya Putu Wijaya
}

\author{
Nur Hamidah, Endang Sri Widayati, Fitri Nura Murti. \\ Jurusan Pendidikan Bahasa dan Seni, FKIP, \\ Universitas Jember (UNEJ) \\ Jln. Kalimantan 37, Jember 68121 \\ E-mail: nurhamidah175@gmail.com
}

\begin{abstract}
Putri is a novel by Putu Wijaya part two that focuses on issues of Indonesian tradition in a specially with a female sword. This study was apply with genetic structuralism, to see the world view author. The method used in this research is the dialectical method. Data and source obtained from the words and paragraphs in the novel through the documentation process and interview with author and narasumber from Bali. The result and discussion of research inlcude, (1) novel structure, namely characters and themes. Characters in a Putri novel shows a picture social life of Balinese, while the theme is a Balinese tradition. (2) social life is influenced by family, education, where to live, and daily activity affect of creation. (3) the world view by Putu Wijaya in a Putri novel related with a traditions which growsand develops with the modernization. Putu Wijaya with a Balinese women succeede in making changes with the society's view of Balinese tradition and women in the process totradition is in contact with the modernization of the realm, the freedom, social politic, and economic should be aligned and equal towards.
\end{abstract}

Keyword : Putri novels, novel structure, author's social life, author world view

\section{Pendahuluan}

Novel sebagai salah satu karya sastra hasil dari pemikiran pengarang yang disajikan dalam bentuk cerita. Cerita tersebut dihasilkan oleh pengarang yang merupakan individu yang berasaldari masyarakat. Cerita novel yang dihasilkan oleh pengarang sebagai cara mengekspresikan pikiran, aspirasi dan juga gagasaanya. Seperti yang diungkapkan oleh Kurniawan, ${ }^{1}$ bahwa "Karya sastra merupakan representasi pandangan dunia pengarang yang mewakili eksistensinya sebagai individu yang hidup di masyarakat". Novel menjadi salah satu karya sastra tulis yang mengandung gagasan, aspirasi dan perasaan pengarang yang disebut dengan pandangan dunia pengarang. Pandangan dunia tersebut dapat diketahui denganmenggunakan kajian strukturalisme genetik.

Strukturalisme genetik merupakan cetusan dari Lucian Goldmann. Goldmann menyatakan novel sebagai sebuah ceritatentang suatu pencarian yang terdegradasi akan nilai-nilai yang otentik yang dilakukan oleh seorang hero yang problematik dalam sebuah dunia yang juga terdegradasi². Nilai-nilai otentik dalam novel mengandung sebuah totalitas kehidupan yang

\footnotetext{
${ }^{1}$ Faruk, Pengantar Sosiologi Sastra: Dari Strukturalisme Genetik Sampai Post Modernisme Ed. $2 \mid$ Fakultas Ilmu Sosial (Yogyakarta: Pustaka Pelajar, 2012), http://fis.uny.ac.id/perpustakaan/koleksibuku/pengantar-sosiologi-sastra-dari-strukturalisme-genetik-sampai-post.

${ }^{2}$ Faruk.
} 
dituliskan secara implisit oleh pengarang ke dalam novel. Totalitas kehidupan yang berasal dari realitas kehidupan disadari oleh tokoh problematik, melalui tokoh problematik itulah maka dapat diketahui pandangan dunia pengarang.

Pandangan dunia pengarang ditelusuri di dalam novel Putrikarya Putu Wijaya melalui problematika antara tokoh Putri tokoh lainnya. Tokoh problematiknya yaitu bernama Putri yang mencoba membawa gerakan perubahan tradisi lama menuju tradisi baru. Terlebih lagi, latar belakang keluarganya yang berasal dari kasta Sudra menjadi sorotan masyarakat tempat tinggalnya. Tidak mudah bagi seorang perempuan yang berasal dari kasta Sudra untuk menyuarakan aspirasi dan gagasannya. Karena pada masa yang telah lalu, kasta masih dijunjung tinggi bagi masyarakat Hindu-Bali dan juga pandangan rendah terhadap kaum perempuan yang hanya dijadikan pelampiasan nafsu dan juga budak bagi kaum laki-laki.

Novel Putri adalah salah satu hasil ciptaan Putu Wijaya. Putu Wijaya merupakan pengarang yang terlahir di Bali, tepatnya di Puri Anom. Putu Wijaya menjadi individu yang mengaspirasikan pandangannya ke dalam sebuah karya salah satunya novel. Novel yang berjudul Putri menjadi bentuk upayanya dalam menyikapi kehidupan sosial budaya sebagai perwakilan kelompok sosialnya. Karena terkenal dengan teror mental-nya dapat menggiring pembaca agar lebih bisa menjernihkan pikiran dan bijak dalam menyikapi suatu peristiwa. Ada beberapa tampilan peristiwa di dalam novel Putriyang harus disikapi secara bijak, agar tidak terjerumus ke dalamkekeliruan yang berkelanjutan.

Berdasarkan latar belakang di atas, fokus masalah dalam penelitian ini adalah; (1) Struktur novel Putri karya Putu Wijaya yang mencerminkan problematika antara tokoh dengan tokoh maupun dengan objek sekitar. (2) Pandangan dunia pengarang dalam novel Putri karya Putu Wijaya.

\section{Metode Penelitian}

Jenis dan rancangan penelitian kualitatif yang digunakan untuk penelitian ini adalah kualitatif deskriptif dengan metode dialektik. Data yang digu nakan dalam penelitian adalah katakata-kata, kalimat, dan paragraf yang mengindikasikan struktur teks novel dan pandangan dunia pengarang. Pengumpulan data yang digunakan dalam penelitian menggu nakan teknik dokum entasi dan wawancara mendalam. Analisis data dalam penelitianini mencakup tahap; 1) reduksi data, 2) interpretasi data, 3) penyajian data, dan 4) verifikasi data. Instrumen yang digunakandalam penelitian ini meliputi; tabel pengumpul data, tabel analisis data, bolpoin, sticky note, buku catatan, laptop, handphone. Prosedur penelitian meliputi tahap 1) persiapan, 2) pelaksanaan, 3) penyelesaian laporan penelitian.

\section{Hasil dan pembahasan}

Analisis data yang dipaparkan pada penelitian ini ada beberapa fokus penelitian. Fokus penelitian didasarkan pada rumusan masalah yang digunakan untuk mencari struktur teks karya sastra dan pandangan dunia pengarang. Pencarian strukturteks karya sastra dapat dilakukan dengan 
mencari hubungan antara tokoh dengan tokoh maupun dengan objek sekitar yang mencerminkan problematika. Problematika ini ditunjukkan oleh beberapa tokoh dengan sajian peristiwa, konflik, dan lain sebagainya. Setelah problematika ditemukan, lalu dapat ditentukan pandangan dunia pengarang dalam novel Putri karyaPutu Wijaya. Berikut hasil dan pembahasan data pada penelitian.

\section{a. Struktur Novel Putri}

Analisis struktur novel Putri karya Putu Wijaya dalam penelitian ini bersifat tematik, artinya berpusat pada relasi antaratokoh maupun dengan objek di sekitarnya. Relasi ini digunaka untuk mengetahui problematika antatokoh maupun dengan o bjeksekitar. Berikut struktur novel Putri karya Putu Wijaya yang tercermin dalam relasi antara tokoh dengan tokoh maupun dengan objek sekitar.

\section{1) Problematika antara Tokoh dengan Tokoh maupundengan Objek Sekitar}

Novel Putri karya Putu Wijaya menampilkan banyak tokoh. Tokoh-tokoh yang ditampilkan tentu saja tidak semuanya. Ada yang menjadi tokoh utama dan tokoh pelengkap. Tokoh utama membentuk alur cerita dari awal hingga akhir cerita, sedangkantokoh pelengkap tidak selalu ada di setiap alur cerita. Hubunganyang diciptakan pengarang dalam novel dapat menggambarkan sebuah problematika. Berikut problematika antartokoh maupun dengan objek sekitar.

a) Problematika Tokoh Putri

Tokoh Putri mendominasi di antara tokoh-tokoh lain oleh karena itu disebut sebagai tokoh hero yang problematik. Hal inidapat diketahui dari hubungan-hubungannya dengan tokoh lain yang ada di dalam cerita. Berikut beberapa hubungan antara tokoh Putri dengan tokoh lainnya.

(1) Problematika Tokoh Putri dengan Abu

Data berikut menunjukkan problematika antara tokoh Putridengan tokoh Abu.

Banjar melihat kepada Abu. Lelaki itu selalu ikut serta dalam kegiatan sosial banjar disela-selakesibukannya berjualan sate. Tidak seorang punpernah mempersoalkan agama. Karena Abu sendiri juga tidak pernah canggung menghadapi berbagai 
kegiatan banjar. Sangat berbeda dengan beberapa tetangga Abu, yang sekali saja pun tidak mau mengikuti kegiatan banjar karena merasa ada perbedaan agama. ${ }^{3}$

Berdasarkan data tersebut menunjukkan begitu luas jiwa sosial yang dimiliki Abu. Ia tidak memandang perbedaan agama atau hal lain dalam membantu. Ia melakukannya dengan ketulusan tanpa melihat adanya keuntungan terutama uang. Perbedaan agama tidak membuat Abu merasa canggung atau terdeskriminasi dengan warga sekitar. Ia sering terlibat dalam kegiatan banjar. baginya, Putri juga demikian. Walaupun keduanya berbeda agama, tetapi mereka bersahabat tanpa permasalahan mempermasalahkan itu. Hanya saja, saat yang tidak tepat tentang pemberian amplop, Abu merasa tersinggung. Ia tidak minta belas kasihan dari orang lain bahkan darisahabatnya sekalipun.

Analisis hubungan antara tokoh Putri dengan tokoh Abu,dapat diketahui bahwa tema yang diangkat oleh pengarang adalah tradisi gotong-royong di Bali tanpa melihat perbedaan agama. Terlihat jelas bahwa tokoh Abu yang bernama lengkap Abu Hanifah dan juga ayahnya yang bernama Abdul Shaleh beragama Islam. Tokoh Putri beragama Hindu dan juga warga sekitar tempat tinggal Abu yang beragama Hindu.

Tercatat dalam sejarah Bali, bahwa penduduk Bali yang beragama Islam sudah ada sejak dulu, di masa kerajaan Hindu Bali pada masa-masa kejayaannya. Muslim masuk karena raja Buleleng yaitu Ki Panji Sakti mendatangkan prajurit dari Blambangan yang beragama Islam untuk membantu pertahanandari kerajaan Gelgel. Sejak dulu, di setiap kerajaan yang ada diBali selalu ada warga yang beragama muslim. Jadi, hal ini sudahmenjadi kebiasaan bagi mereka. Orang Bali menyebut muslim dengan sebutan nyama selam. Kedua agama tersebut tidak ada pertentangan, melainkan ada sebuah akulturasi atau pembauran budaya yang berakar dari persamaan tradisi. Misalnya pembauran budaya tersebut dapat dilihat dari sistem subak,umumnya digunakan oleh petani Hindu. Melalui sistem subak tersebut, ternyata di petani Islam juga bisa menerima, tetapi keduanya memiliki cara berdoa yang berbeda-beda. Masih banyak tradisi-tradisi yang menjunjung tinggi kerukukan dengancara gotong royong seperti pada saat umat Hindu melakukan pratima $(\text { ogoh-ogoh) })^{4}$ dalam bukunya tentang tradisi Bali mengatakan bahwa "Saya pernah melihat iringiringan umat Hindu yang mengusung pratima berhenti di jalan dan gamelan pun tidak ditabuh. Karena poisi berhentinya tidak menunjukkan mereka beristirahat, dan jalanan sedikit tersendat,

\footnotetext{
${ }^{3}$ Putu Wijaya, Putri (Grafiti, 2004).

${ }^{4}$ Putu Setia, Bali Menggugat (Kepustakaan Populer Gramedia, 2014).
} 
saya sempat bertanya, apa yang terjadi? Salah seorang menjawab: "Di depan ada masjid, mereka lagi sembahyang." Dan betul, di depan masjid saat itu umat muslim sedang khusyuksholat Jum'at.

Berdasarkan pemaparan tersebut, salah satu kegiatan yang ditampilkan pada novel Putri adalah kegiatan banjar adalah tradisi gotong-royong. Gotong royong sudah menjadi tradisi yang dijunjung tinggi oleh masyarakat banjar. Tradisi gotong royong ini juga menjadi bagian yang diatur dalam masyarakat banjar. Jika ada salah satu anggota keluarga yang hidup di banjar meninggal, maka sudah ada ketetapan daribanjar untuk saling membantu. Bantuan tersebut berupa materi maupun non-materi. Bantuan dari banjar ini juga tidakmemandang ras, suku, agama seseorang. Siapapun yang berada dan hidup dalam banjar tersebut, maka ia berhak mendapatkan bantuan dari warga banjar setempat. Seperti yang telah didapatkan oleh Abu.

(2) Problematika Tokoh Putri dengan Mangku Puseh

Berikut adalah data yang menunjukkan hubungan problematika antara tokoh Putri dengan Mangku Puseh.

"Saya mengerti, Bapa sedang mendorong saya untuk melakukan sesuatu. Ya kan Bapa?" Mangku Puseh menarik napas. Suaranya lemah. "Bapa tidak mendorong. Bapa meminta, Luh.” 
Putri tertegun. Tiba-tiba semuanya terbalik. Setelah dipuji, ia diberi misi. Putri dengan halus mencoba menolak.

"Tapi saya orang yang lemah, Bapa. Saya tidak akan mampu memenuhi permintaan Bapa."

Data tersebut menunjukkan bahwa tokoh Mangku Puseh menginginkan tokoh Putri untuk melakukan sesuatu. Sesuatu yang dimaksudkan oleh tokoh Mangku Puseh terebut adalah melamar tokoh Ngurah Wikan. Berdasarkan percakapan tersebut, tokoh Putri menolak secar halus

Berdasarkan analisis data di atas, tema yang diangkat oleh pengarang adalah tradisi perkawinan nyentana. Nyentana adalahjenis proses perkawinan antara seorang perempuan dengan laki-laki, dimana pihak laki-laki dilamar oleh pihak perempuan dan pihak laki-laki bersedia meninggalkan keluarga beserta hak dan kewajibannya sebelumnya. Pihak laki-laki juga harus bersedia tinggal di kediaman istrinya serta bertanggung jawab atas segalasesuatu yang berada di rumah istrinya. Ketika seorang laki-laki bersedia nyentana, berarti pihak perempuan otomatis akan menjadi kepala keluarga, sedangkan pihak laki-laki sebaliknya. Beserta kasta yang dibawa pihak laki-laki tidak bermakna lagi, artinya dia harus mengikuti kasta perempuan (istrinya).

Menurut adat Bali, Ter Haar (dalam Yasin, 2014) menyebutkan bahwa "Hanya anak laki-laki yang dapat meneruskan peninggalan bapaknya dan dapat melanjutkankedudukannya sebagai kepala keluarga. Jika tidak ada anak laki-laki, maka dapatlah seorang anak laki-laki diambil anak, baik oleh si bapak maupun oleh jandanya atas nama dia jika sibapak meninggal. Sebagai gantinya dapatlah si bapak mengangkat anaknya perempuan menjadi sentana. Anak perempuan itu diberikan hak-hak dan kewajiban sebagaimanaseorang anak laki-laki.”

(3) Problematika Tokoh Putri dengan Dadong dan Wayan Sadra

Pada saat kematian Mangku Puseh, ada beberapa hal yang terjadi antara tokoh Putri dengan anggota keluarga. Anggota keluarga tersebut ialah dadong dan Wayan Sadra. Berikut problematika antara tokoh Putri dengan tokoh dadong.

\footnotetext{
${ }^{5}$ Wijaya, Putri.
} 
"Tapi begitu rencana Putri memilih upacara nista terdengar, langsung muncul tantangan keras dari keluarga dan penduduk Meliling. Dadong Putri yang sudah sakitsakitan, tiba-tiba beringas dan ngamuk ketika anak yang paling dicintainya mau diaben dengan upacara nista. "6

Dadong, adalah sebutan nenek dalam bahasa Bali. Sebagai salah satu orang yang menentang keputusan Putri, ia tidak terimakalau anaknya, Mangku Puseh harus di-ngaben dengan upacara nista. Sesuai dengan ketentuan adat, seorang Pemangku Desa Adat biasanya dipilihkan dengan tingkatan utama (besar). Hal ini dikarenakan posisi pemangku adat sangat dihormati oleh warga desa adat setempat.

Selain itu, pertentangan muncul dari kakaknya, Wayan Sadra. Wayan Sadra seolah-olah tedun (kerasukan roh). Berikut datanya.

"Mentang-mentang sekolah kamu tinggi, mentang-mentang sekarang kamu kaya, mentang- mentang sekarang aku sudah mati, berani- beraninya kamu mau membakar aku sepertimembakar ayam. Kamu anak tidak tahu diri. Jual rumahku, jual sawahku, jual pabrik kaus kamu itu,beri aku upacara yang layak. Aku tidak mau upacara nista, aku mau upacara utama. Aku mau tidur di rumahku 40 hari sebelum aku disucikan disetra. Jangan perlakukan aku seperti orang hina, aku Mangku Puseh, aku sudah mengabdi puluhan tahun untuk desa Meliling. Pukul kentongan, suruhsemua warga desa bergotong-royong membuatkanaku wadah utama."

Data di atas menunjukkan bahwa Wayan Sadra memintaagar pengabenan Mangku Puseh dilaksanakan dengan tingkatanutama, tetapi Putri menolaknya. Wayan Sadra mencari-cari alasan salah satunya dengan tindakan seolah-olah kerasukan roh(tedun). Wayan Sadra seolah-olah kerasukan roh tokoh MangkuPuseh berharap tokoh Putri mengabulkan permintaanya. Tokoh Wayan Sadra mencaci maki tokoh Putri karena ia seorang sarjana, maka ia dapat sewenang-wenang memilih tingkatan upacara sesuai keinginannya dan tidak mau mematuhi peraturandesa adat. Bahkan, tokoh Wayan Sadra mengucapkan apa saja yang menurutnya benar. Ia meminta agar tokoh Putri menjual harta benda yang dimiliki oleh tokoh Mangku Puseh. Jika tidak cukup, maka

\footnotetext{
${ }^{6}$ Wijaya.

${ }^{7}$ Wijaya.
} 
tokoh Putri harus rela menjual pabrik kaosnya. Halini tentu saja memberatkan bagi tokoh Putri. Tokoh Putri pun menyangkal kemauan tokoh Wayan Sadra tersebut

Analisis data di atas, tema yang diangkat oleh pengarang adalah tentang pelaksanaan upacara ngaben yang selalu berorientasi pada tingkatannya, bukan maknanya. Peristiwa yang dialami oleh tokoh Putri, koheren denganperistiwa pengabenan yang ada di Hindu Bali. Sebelum tahun 1979-an, pelaksanaan upacara ngaben selalu dilaksanakan dengan megah dan besasbesaran. Banyak persiapan- persiapan yang harus dilakukan mulai dari sebelum, saat, dansesudah ngaben. Tentu saja hal ini merepotkan. Banyak biaya,waktu, dan tenaga yang harus dikeluarkan untuk pelaksanaanngaben. Tokoh Putri juga akan merasakan hal yang sama jikasaja pelaksanaan upacara ngaben yang diplihnya adalah tingkatan utama. Akan tetapi, sejak tahun 1979, upacara ngaben tidak harus dilaksanakan dengan biaya yang mahal dan berhura-hura. Pada tahun tersebut mulai diresmikan ngaben secara kolektif yang diresmikan oleh PresidenSoeharto yang pada saat itu dianggap sebagai raja karena sejakkemerdekaan, raja Bali sudah tidak ada lagi. ${ }^{8}$ Sejak saat itulah masyarakat bebas menentukan ngaben yang akan dilaksanakan, baik itu secara sederhana maupun besar- besaran. Ajaran Hindu juga tidak membatasi tingkatan yang harus dipilih, baik itu utama, madya, maupun nista sesuai dengan kemampuan. Problematika Tokoh Putri dengan Kepala Desa Adat

Pertentangan ngaben juga terjadi antara tokoh Putridengan masyarakat setempat. Berikut datanya.

"Tidak ada yang menghalang-halangi, Luh. Siapa yang menghalangi-halangi. Apalagi sekarang sudah zaman reformasi. Silakanlaksanakan apa yang Luh inginkan, asalkanjangan membuat masyarakat gelisah. Kita hidup dalam satu desa, setiap orang merdeka untuk melaksanakan apa yang diyakininya, asal tidak melanggar yang diyakini oleh orang lain. Kita bukan binatang di dalam rimba. Di dalam bermasyarakat ada yang sudah menjadi kesepakatan kita bersama, yang wajib dihormati!'

Putri tertegun

"Jadi kalau begitu, Bapa datang kemari untuk menyuruh saya menaati apa

\footnotetext{
${ }^{8}$ Setia, Bali Menggugat.
} 
yang sudah menjadi kesepakatan bersama?" 9

Data di atas menunjukkan bahwa tokoh Kepala Desa Adat tidak setuju dengan keputusan tokoh Putri dalam memilih ngaben tingkatan nista. Perbedaan pandangan antara keduanya sangat jelas bahwa Kepala Desa Adat sebagai pemimpin dan dianut oleh warganya, maka ia harus mematuhi aturan desa adatyang telah dibuat dan disepakati. Di dalam kehidupan bermasyarakat, tokoh Putri memang seharusnya menaati peraturan yang sudah dibuat. Akan tetapi, jika peraturan yang dibuat tidak sesuai dengan apa yang telah diajarkan oleh sesuatuyang disebut agama, karena seharusnya aturan agama memiliki kedudukan yang lebih tinggi daripada aturan yang dibuat oleh manusia.

Analisis data-data di atas, tema yang diangkat oleh pengarang adalah akibat menentang peraturan desa adat. Desa adat menurut I Gusti Gede Raka ${ }^{10}$ sdalah suatu kesatuan wilayah dimana warganya mengonsepkan dan mengaktifkan upacara-upacara keagamaan untuk memelihara kesucian desa. Kesatuan ini didasari oleh tiga hal yaitu karang desa (wilayah teritorial desa), awig-awig (sistem aturan desa dengan aturan pelaksananya), dan pura kahyangan (tempat sembahyang). I Wayan Surpha (1993:56) mengatakan bahwa desa adat memiliki tugas dan wewenang. Wewenang tersebut adalah melaksanakan ayahan desa (tugas-tugas krama desa) dan wajib tunduk dan menaati peraturan-peraturan yang berlaku bagi desa adat tersebut. Dalam pelaksanaannya peraturan desa adat yang disebut dengan awig-awig ada beberapa hal pokok yang diatur mulai dari batas desa, perangkatdesa, rapat desa, upacara desa dan lain-lain.

Pembahasan yang relevan dengan data-data di atas dan terkait dengan problematika antara tokoh Putri dengan tokoh Kepala Desa Adat adalah tentang awig-awig upacara (kelahirankematian). Menurut I Wayan Surpha dalam tulisannya tersebut mengatakan kewajiban utama desa dalam pelaksanaan upacara adalah menjunjung tinggi agama, awig-awig (teknis) hendaknya memperlancar pelaksanaan upacara, bukan menghambat. Oleh karena itu, seperti yng tokoh Putri pikirkan bahwa pelaksanaan ngaben seharusnya tidak menghambat roh kembali ke Tuhan

\footnotetext{
${ }^{9}$ Wijaya, Putri.

${ }^{10}$ I. Ketut Sudarsana, "NGABEN WARGA DADYA ARYA KUBONTUBUH TIRTHA SARI DESA ULAKAN KARANGASEM (Perspektif Pendidikan Agama Hindu)," Jayapangus Press Books, February $15,2018, \mathrm{i}-129$.
} 
Yang Maha Esa. Kembalinya roh kepada Tuhan tidak terletak pada segala sesuatu seperti banten, bade dan lain-lain, melainkan yang terpenting adalah maknanya.

(4) Problematika Tokoh Putri dengan Ngurah Wikan

Tokoh Ngurah Wikan adalah bangsawan keturunan Puri Puncak. Berikut data yang menunjukkan problematika antara tokoh Putri dan Ngurah Wikan.

"Kamu keliru! Aku tidak mau keputusanku menjadi semacam pemberontakan. Aku tidak ingin kelihatan keluar dari Puri sebagai konfrontasi. Aku sedang tidak memelopori sesuatu. Aku tidak sedang menentang sesuatu. Aku sedang tidak mememperjuangkan sesuatu. Aku hanya mencoba kehidupan tradisi yang tidakbisa lagi aku pikul itu. Aku tak ingin jadi pahlawan. Aku seorang pelarian biasa yang pengecut." ${ }^{11}$

Data tersebut menunjukkan problematika antara tokoh Putri dan Ngurah Wikan tentang dilema antara cinta dan keluarga. Tokoh Putri dengan keberaniannya melamar tokoh Ngurah Wikan. Ngurah Wikan dengan segala kebimbangannya antara Putri atau Puri. Tentu hal ini menjadipertimbangan besar bagi Putri. Putri harus mengesampingkan rasa malu dan statusnya untuk melamar kepada seorang bangsawan seperti Ngurah Wikan. Jika pun ditolak oleh Ngurah Wikan, bagi Putri bukan sesuatu yang harus disesali karena keputusannya melamar Ngurah Wikan sudahkeputusan bulat. Berani mengambil keputusan melamar seorang bangsawan, maka harus siap menerima risikonya karena tidak banyak perempuan yang berani memutuskan untuk melakukan nyentana seperti yang dilakukan Putri.

Berdasarkan analisis data di atas, tema yang diangkat oleh pengarang adalah pelaksanaan proses perkawinan nyentana yang dilakukan oleh tokoh Putri. Tradisi nyentana ini masih sedikit dilakukan oleh warga Bali bahkan sampai sekarang khususnya di daerah Tabanan hanya 1\% yang melakukan nyentana. Persentase ini didapatkan dari data divisi perkawinan dan perceraian kabupaten Tabanan. Perkawinan nyentana di Bali hanya berlaku untuk beberapa kabupaten saja seperti kabupaten Tabanan, Gianyar, dan Negara. Bahkan warga Karangasem menolak pelaksanan perawinan nyentana (Ida Padanda Rai Manuaba, 2015). Jika pelaksanaan nyentanaini dilakukan, maka dikhawatirkan akan memengaruhi hak waris dan keturunan. Problematika yang dihadapi

\footnotetext{
${ }^{11}$ Wijaya, Putri.
} 
tokoh Putri dan tokoh Ngurah Wikan relevan dengan masalah yang terjadidi Bali khususnya Hindu-Bali. Jika Ngurah Wikan rela nyentana, ia harus rea melepaskan hak waris dan sepenuhnya ia menjadi milik Putri bahkan statusnya juga. Selain itu, dalamperkawinan nyentana, jika seorang laki-laki yang sudah nyentana dan berpisah dengan pihak perempuan, maka tidak bisa mendapatkan kembali hak waris dan kasta sebelumnya. Apabila perkawinan itu bertahan hingga memiliki keturunan, maka kasta keturunan dari perkawinan tersebut otomatis akanmengikuti kasta pihak perempuan. Seiring perkembangan zaman, adat perkawinan nyentana seperti ini masih sangat berlaku untuk zaman dahulu akan tetapi, sekarang sudah mulai lentur terutama masalah kasta. Masalah sistem kasta dalam perkawinan mulai terabaikan. Semakin banyak yang menyadari bahwa ada sebagian tradisi yang sudah tidak relevan dengan zamansekarang. Hanya ada sebagian kecil yang masih memegang teguh tradisi ini. Sebagai contoh adalah dari kasta Brahmana,karena status kasta ini yang paling tinggi dan harus hati-hatidalam memilih pasangan. Dayu mengatakan bahwa "sudah banyak yang mengabaikan sistem kasta dalam adat perkawinan. Sekarang sudah tergeser karena adanya globalisasi. Hanya sebagian saja yang memegang tradisi ini.Seperti keluarga saya yang berasal dari kasta Brahmana" (wawancara, 14 Februari 2020). Dayu juga menambahkan bahwa sistem kasta untuk zaman sekarang tidak kaku, maksudnya jika berbeda kasta, maka bisa dirundingkan antarpihak keluarga. Oleh karena itu, kasta bukanlahmasalah besar bagi. Seperti yang telah dilakukan oleh tokohPutri dan juga Ngurah Wikan, yaitu dengan merundingkan dengan pihak keluarga terlebih dulu.

b) Problematika Tokoh Ngurah Wikan

Struktur novel yang mencerminkan problematika antara tokoh dengan tokoh juga terjadi pada tokoh Ngurah Wikan.Tokoh Ngurah Wikan sebagai tokoh pelengkap yang memiliki porsi penceritaan cukup banyak. Oleh karena itu memiliki hubungan-hubungan dengan banyak tokoh lain yang memungkinkan sebuah problematika. Berikut merupakan data yang menggambarkan problematika antara tokoh Wikan dengan tokoh-tokoh lain.

(1) Problematika Tokoh Ngurah Wikan dengan MargarethData berikut untuk mengetahui hubungan antara

tokoh Wikan dengan tokoh Margareth. 
“Kalau gitu kamu akan menghancurkan Puri.”"Jelas sekali itu bukan tujuanku!”

"Itu tujuanmu."

Ngurah menatap Ngurah.

"Hubunganmu dengan Puri bukan hubungan fisikyang bisa diukur dengan satuansatuan yang konkret. Hubunganmu adalah ikatan batin, Ngurah. Sesuatu yang tidak bisa dilenyapkan." 12

Data menunjukkan akibat jika Ngurah Wikanmemutuskan hubungan dengan kerabat bukan menjadi pilihan yang terbaik. Keluar dari Puri, berati akan mencorengnama baik Puri itu sendiri. Puri selama ini menjadi panutan.Jika ada seseorang yang keluar dari Puri, maka akan ada halyang perlu dipertanyakan tentang kehidupan di dalamnya. Tentu saja akan membuat nama-nama yang kurang baik di mata masyarakat. Seperti itulah yang diinginkan oleh sesepuh Puri melalui tokoh Margareth. Walaupun sebenarnya tujuan utama tokoh Ngurah Wikan bukan untuk menghancurkan Puri, tetapi secara tidak langsung hal itu akan berpengaruh juga dengan nama baik Puri.

Berdasarkan analisis data di atas, tema yang diangkat oleh pengarang adalah tentang dinamika kehidupan di Puri. Puri adalah simbol kekuasaan politik raja. Pembangunan Puri-puri yang ada di Bali adalah bentuk pelestarian untuk menjaga kesinambungan kerajaan (Majapahit). Puri-puri yang ada di Bali pernah hancur pada tahun 1600-an dan muncul Puri-puri baru pada abad ke 17. Hancurnya Puri yangada di Bali karena pemberontakan yang dilakukan oleh para pejabat-pejabat tinggi yang ada di Puri. Jika dilihat dari duaaspek, yaitu aspek sosial dan politik, maka dalam aspek sosial Puri adalah tempat tinggal bagi raja dan seluruh kerajaan. Jika dilihat dari aspek politik, maka Puri dijadikan pusat pemerintahan ${ }^{13}$ Hal ini koheren dengan yang dilakukan oleh Ngurah Wikan terhadap Puri. Ngurah Wikan diibaratkan sebagai seseorang yang memilikijabatan tinggi di suatu kejaraan, tetapi ia memberontak makabisa menghancurkan isi di dalam suatu pemerintahan tersebut. Akan tetapi hal itu bukan acuan, karena Ngurah Wikan tidak bermaksud untuk menghancurkan Puri dengan segala isinya. Ia hanya ingin terbebas dari segala tradisi yangmengikat di dalam Puri. Hidup di Puri, berati memiliki statuskebangsawanan

\footnotetext{
${ }^{12}$ Wijaya.

${ }^{13}$ Agus Aris Munandar, Istana Dewa Pulau Dewata : Makna Puri Bali Abad Ke-14 - 19 (Komunitas Bambu, 2005).
} 
dan juga status sosial yang tinggi. Status itulah tersebut tidak diinginkan oleh Ngurah Wikan.

(2) Problematika Tokoh Ngurah Wikan dengan Rai Berikut adalah data yang digunakan untuk

mengetahui hubungan antara tokoh Ngurah Wikan dan tokoh Rai.

"Kakek-kakek saya dulu petani biasa. Kamiorang sudra. Kami termasuk juru tandurPuri (penggarap tanah milik orang Puri). Kami sangat miskin, tetapi kakek kami berpikiran maju. Banyak anggota keluarga kami yang ngotot sekolah dan berhasil menjadi dokter dan insinyur. Dalam revolusi, banyak andil kami. Kami punya beberapa pahlawan di Makam Pahlawan Pancaka Tirtha. Akhirnya kami membelikasta dari orang yang bisa menuliskan pipil. Pada mulanya kami ditentang. Tapi setelah banyak dari anggota keluarga kami melakukan perkawinan perkawinan denganorang-orang Puri, apalagi keluarga kamimaju dalam berdagang, akhirnya semua orang menerima kami sebagai keluarga besar Pur. Ngurah percaya?"14

Data menunjukkan bahwa tokoh Rai tidakmendapatkan gelar kebangsawanan dengan percuma seperti Ngurah Wikan. Jika Ngurah Wikan mendapatkannya karena garis keturunan dari nenek moyangnya, maka garis keturunan Rai berbeda. Leluhur Rai harus berupaya keras agar mendapatkan gelar kebangsawanan tersebut dengan cara meningkatkan kualitas SDM dan juga melakukan perkawinandengan orang-orang Puri.

Analisis data di atas, tema yang diangkat oleh pengarangadalah problematika perolehan gelar kebangsawanan dari PuriBali. Bagi masyakat Bali, Puri bukan hanya sebagai tempat tinggal melainkan sebagai tempat yang luhur dan berisi keluhuran. Seperti yang dikatakan oleh I Putu Gede Suwitha (2019) bahwa Puri berfungsi sebagai pengayom umat agama Hindu, bahkan sebagai identitas politik karena mendominasi kultural masyarakat dan juga berkembang sebagai penopang kepariwisataan di Bali. Pada pernyataan tersebut, Rai dapat membaca bahwa Puri memiliki kemampuan beradaptasi dengan modernitas. Dibuktikan dengan sebuah hotel yangdimilikinya sekarang. Selain masih memiliki dominasi kultural di masyarakat juga sebagai penopang

\footnotetext{
${ }^{14}$ Wijaya, Putri.
} 
kepariwisataan di Bali. Penelitian yang dilakukan oleh I Gede tersebut dikuatkan oleh pernyataan Geertz (1974) bahwa orang Bali cenderung cepat berubah dan cepat meniru, mudah menerima sesuatu dari luar dan kemudian menjadikan miliknya sendiri.

Berdasarkan pemaparan semua data beserta analisis hubungan antara tokoh dengan tokoh maupun dengan objek sekitar di atas, maka dapat diketahui bahwa tokoh utama(tokoh problematik) pada cerita adalah tokoh Putri. Tokoh Putri disebut juga sebagai hero yang problematik karena berusaha mencari nilai yang terdegradasi dalam dunia yang terdegradasi juga. Tokoh Putri berusaha mencari nila-nilai yang dianggap sesuai dengan tradisi dan ajarannya dengan sebuah tradisi baru dan pemikiran yang baru. Selain itu, tokohPutri dijadikan sebagai tokoh problematik karena paling banyak berhubungan dengan tokoh lain, terlibat dalam problematika hampir pada setiap tokoh, dan paling banyak diceritakan dibandingkan tokoh lain/bawahan. Adapun tokoh bawahan dalam novel Putri karya Putu Wijaya buku kedua iniyakni Ngurah Wikan, Abu, Mangku Puseh, Wayan Sadra, Kepala Desa Adat, Masyarakat desa Meliling, Dadong, Margareth, dan Rai. Tokoh-tokoh bawahan tersebut tentu saja tidak disebutkan semua, melainkan hanya beberapa saja yang memiliki problematika dengan Putri dan disesuaikan dengan alur dan tema yang dibahas dalam penelitian. Tokoh-tokoh yang berhubungan dengan Putri yakni Ngurah Wikan, Abu, Mangku Puseh, Wayan Sadra, Dadong, Kepala Desa Adat.

Analisis hubungan struktur antara tokoh dengan tokoh maupun objek sekitar, dapat diketahui juga tema dan latar yang digunakan oleh pengarang. Tema yang digunakan oleh pengarang dalam novel Putri adalah tema problematika yang dialami masyarakat dengan latar tradisi Bali. Problematika tersebut meliputi, 1) problematika masyarakat Bali dalam menjaga dan melestarikan tradisi yang sudah ada yaitu gorong- royong, 2) problematika masyarakat dalam menghadapi tradisi yang sudah tidak relevan lagi dengan kondisi zaman. Tokoh novel Putri, dalam menghadapi problematika tersebut melakukan tindakan-tindakan nyata yang seharusnya dilakukan.Seperti contoh dalam pelaksanaan nyentana, tokoh Putri berani melakukan prosesi tersebut karena tradisi yang dibenarkan olehadat tersebut tidak banyak dilakukan. Banyak yang merasa khawatir karena hak waris dan keturunan. Tindakan lain yang dilakukan oleh tokoh Putri adalah dengan melakukan pemilihan upacara tingkat nista untuk seseorang yang memiliki kehormatan. Seharusnya, untuk seseorang yang memilikikehormatan, harus diupakari dengan tingkat utama. Bukan hanya tokoh Putri yang melakukan tindakan pertentangan, tokohlainnya 
adalah Ngurah Wikan yang melepaskan statuskebangsawanannya dari Puri. Orang lain bersikeras un tuk mendapatkan gelar kebangsawanan, akan tetapi Ngurah Wikan melepas gelar karena ingin kebebasan. Tokoh Ngurah Wikantidak ingin terikat sebuah tradisi yang ada di dalam Puri.

Keseluruhan gambaran problematika di atas, dapat ditarik kesimpulan bahwa probematika yang terjadi antara tokoh dengan tokoh maupun dengan objek sekitar dilatarbelakangi oleh sebuah tradisi, baik itu yang menyangkut agama, sosial, budaya, maupun politik. Problematika yang dialami oleh tokoh-tokoh dalam novel Putri, adalah gambaran masyarakat dalam menghadapi tradisi Bali. Berdasarkan problematika- problematika tersebut dapat terlihat realita kehidupan masyarakat Hindu-Bali.

\section{b. Kehidupan Sosial Budaya Pengarang yang Berhubungan dengan Novel Putri}

Putu Wijaya adalah individu yang terlahir dari masyarakat Bali. Keadaan lingkungan masyarakat PutuWijaya membentuk kepribadian secara individu maupun lingkungan sosialnya. Kepribadian Putu Wijaya tidak terlepasdari peran keluarganya. Berasal dari keluarga besar Puri Anom, Tabanan yang merupakan golongan keluargabangsawan di Bali membuatnya mengetahui seluk-beluk kehidupan Puri. Berikut bukti bahwa Putu Wijaya berasal darikehidupan Puri juga dicerminkan di dalam novel Putri. Berikutakan dipaparkan beberapa data yang menunjukkan hubungan kehidupan sosial Putu Wijaya dengan novel Putri.

\footnotetext{
"Kewajiban Puri kadang lebih penting darikewajiban menyejahterakan anak dan istrimereka. Puri berarti leluhur, cikal- bakal mereka, tempat dari mana mereka berasal. Tanpa leluhur, mereka tidak mungkin ada. Karenanya, kepentingan Puri dianggap lebih penting dari kepentingan pribadi, selama mereka masih tinggal di dalam Puri. Meskipun mereka gembira, melihat tindakan Ngurah, tidak ada yang berani mendukung secara terangterangan." 15
}

Data di atas menunjukkan bahwa tokoh Ngurah yangmenginginkan untuk memutuskan

\footnotetext{
${ }^{15}$ Wijaya.
} 
hubungan dengan Puri, sangat koheren dengan yang dilakukan oleh Putu Wijaya. Putu Wijaya sebenarnya bernama lengkap I Gusti Ngurah Putu Wijaya. Nama itu didapatkan karena garis keturunannya dari Puri Anom. Sejak duduk di bangku SMP, Putu Wijaya sudah memiliki kegemaran dalam mengarang. Mengarang bagi Putu Wijaya adalah bekerja, memeras keringat otak, dan juga ibadah. Dari kegemarannya mengarang inilah Putu Wijaya menuangkan segala kesadaran atas lingkungan kehidupannya. Sejak saat itulah Putu Wijaya menulis dengan kesadaran untuk memberontak pada tradisi tetapi sama sekali tanpa rasa benci. Dunia luar memberikan gambaran baru kepada Putu Wijaya. Selama hidup di Puri, hidupnya sesak dengan upacara-upacara yangharus dilihatnya setiap hari. Selain itu, hidup di Puri juga harus menjaga sopan santun karena benteng untuk kehidupanmasyarakat Hindu-Bali.

Bukan hanya kegemaran mengarang sejak kecil, tetapi Putu Wijaya juga gemar membaca. Buku-buku yang yang sering menjadi bahan bacaan bagi Putu Wijaya adalah karya Karl Max, Rudyard Kipling, William Saroyan, Hans Christian Andersen, R.A. Kosasih, Pamoedya Ananta Toer, Amir Hamzah, Chairil Anwar dan lainnya. Dengan buku- buku tersebut, Putu Wijaya banyak berpetualang ke dunia luar. Putu Wijaya juga gemar berpetualang ke jalanan untukmelihat pertunjukkan wayang dan suka berkeliling ke penjual jamu/obat di pasar Tabanan. Berdasarkan kegemaran-kegamaran inilah memengaruhi proses kreatifnya dalam mengarang. Banyak karya-karya yang bertema jalanan, tradisi, dan juga memajukan kepercayaan diri Putu Wijaya dalam memunculkan distorsi atau ketakdugaan atau kejutan atau sering sering disebut dengan istilah teror mental.

Sejak lulus SMA, Putu Wijaya telah menetap di luar Bali yaitu Yogyakarta. Putu Wijaya melanjutkan studi ke Fakultas Hukum Universitas Gadjah Mada. Di Yogyakarta, Putu Wijaya bergabung dengan Bengkel Teater yang didirikan oleh W.S. Rendra. Dengan pengalaman hidup yangdidapatkan dari Bengkel Teater tersebut, Putu Wijaya banyak belajar dari W.S. Rendra. Pada tahun 1969 Putu Wijaya berpindah ke Jakarta karena kondisi ekonomi keluarganya mengarahkan Putu Wijaya harus pindah ke Jakarta untuk mencari penghasilan tambahan. Di Jakarta, ia mendapatkan pekerjaan menjadi wartawan. "Hidup ini penuh dengan kecelakaan, kecelakaan yang kadang-kadang disengaja.”, tulisnya dalam sinopsis singkat novel Putri.Putu Wijaya tidak pernah terpikir bahwa dia akan menjadi jurnalis, bermula dari majalah Ekspress pada 1969, lalumajalah Tempo pada 1971-1979, dan majalah Zaman pada 1979-1985. Sebagian upah yang didapatkan oleh Putu Wijaya dikirimkan kepada orang tuanya yang ada di Bali. 
Pekerjaan yang dilakukan oleh Putu Wijaya ini tampak koheren dengan pekerjaan yang dilakukan oleh tokoh Putri. Tokoh Putri adalah satu-satunya sarjana di desanya yang berusaha keras untuk membantu keluarga dan masyarakat desa setempat degan cara mendirikan pabrik kaos. Korelasi yang tampak antara Putu Wijaya dan tokoh Putri adalah tindakan yang dilakukan untuk mengupayakan yang terbaik untuk dirinya sendiri dan juga keluarganya.

Kehidupan sosial Putu Wijaya yang berhubungandengan novel Putri juga terdapat dalam kutipan berikut.
"Selama di Tokyo, Punya waktu banyak sekali untuk berpikir. Seluruh pengalaman yang tak sempat benar-benar direnungkannya, kembali menyapa minta disidangkan. Ia pun sibuk mengusut dan menemukan banyak kekeliruan. Ribuan kilometer dari Meliling, banyak kejadian tampak menjadi lebih jelas. Ia sudah tersipu dan menjadi korban kecanggihan menjawab persoalan." 16

Data di atas menunjukkan bahwa tokoh Putri sedang berada di Tokyo, tepatnya di Ittoen. Kehidupan sosial budaya yang ada di dalam novel Putri juga mencerminkan kehidupan sosial yang dialami oleh Putu Wijaya. Pada 1973,Putu Wijaya mendapatkan beasiswa untuk berlatih drama ke Jepang tepatnya di Ittoen, Yamashina, Kyouto, Jepang. Di Jepang, Putu Wijaya banyak belajar tentang kebudayaan masyarakat Jepang. Salah satu semboyan yang terkenal di negara tersebut adalah "Kerja adalah ibadah."

Keberadaan Putu Wijaya di suatu tempat, tidak memengaruhi identitasnya. Putu hanya ingin menjadi orang Indonesia. Di mana pun Putu Wijaya berada, baik itu di Jakarta, Yogyakarta, Jepang, maupun Amerika Serikat pun tidak memengaruhi identitasnya. Putu Wijaya tidak pernah menampilkan identitasnya sebagai orang Bali, akan tetapi Putu Wijaya mengakui bahwa saat proses kreativitas memorike-Bali-annya kembali begitu saja dan hampir setiap karyanya menyinggung budaya masyarakat Bali. Walaupunsebenar nya yang ingin disinggung oleh Putu Wijaya bukan hanya budaya Bali, melainkan Indonesia. Bahkan saat menulis novel Putri, Putu Wijaya juga menyebutkan bahwa kadang ia berada di Denpasar, Jakarta, Pelabuhan Ratu, Bandung, dll (Wawancara, 5 Februari 2020). Karena Putu Wijaya pernah tinggal di Bali dengan segala

\footnotetext{
${ }^{16}$ Wijaya.
} 
kehidupanmasyarakat sekitarnya, tentu saja sudah melekat dalam hidupnya.

Berdasarkan analisis data-data di atas maka dapat disimpulkan bahwa kehidupan sosial Putu Wijaya baik itu dikeluarga, lingkungan tempat tinggal, riwayat pendidikan, dan kegiatan sehari-hari sangat berpengaruh dalam penciptaan novel Putri. Latar belakang kehidupan sosial keluarganya dan identitasnya sebagai orang Bali tidak dapatdilepaskan begitu saja.

\section{c. Sejarah atau Peristiwa Sosial Masyarakat yang Melatarbelakangi Terciptanya Novel Putri}

Lahirnya novel Putri dilatarbelakangi oleh beberapa peristiwa yang ada di Indonesia khususnya di Bali.Beberapa peristiwa yang melatarbelakangi lahirnya novel Putri meliputi tradisi maupun budaya yang berkembang di masyarakat Bali dan juga kehidupan politik serta tradisi di dalam Puri. Peristiwa pertama yang tercermin dalam novel Putri adalah tentang tradisi gotongroyong antara masyarakat Bali yang berbeda agama.

Peristiwa kerukunan antarumat yang berbeda agama di Bali ditunjukkan di desa Pagayaman, sebelah Selatan kota Singaraja yang berjarak sekitar sembilan kilometer khususnya di Bali bagian utara sebagian besar penduduk beragama Islam. Masyarakat Bali menyebut orang-orang muslim disana dengan sebutan nyama selam. Nyama selam berati orang-orang yang beragama Islam, sebutan ini digunakan untuk menunjukkan persahabatan yang tulus. Panggilan ini bermula karena masyarakat Bali pedesaantidak biasa mengucapkan awalan Is. ${ }^{17}$

Warga Islam yang ada di Bali sebagian besar mengakuseratus persen anggota Nahdlatul Ulama. Oleh karena itu, mereka masyarakat Bali yang beragama Islam tidak risih dengan budayabudaya yang Bali. Perbedaan agama ini tidak menimbulkan perpecahan, melainkan semaki $\mathrm{n}$ menambah keharmonisan. Jika ada perayaan yang dilakukan oleh agama Hindu di Bali, dan melewati masjid maka mereka berhenti membunyikan alat musik yang mereka bawa. Begitu pula dengan warga muslim ketika Hindu merayakan pelaksanaanHari Raya Nyepi tidak ada protes resmi yang dilakukan olehumat muslim. ${ }^{18}$

Peristiwa kedua yang melatarbelakangi lahirnya novel Putri adalah tentang adat

\footnotetext{
${ }^{17}$ Setia, Bali Menggugat.

${ }^{18}$ Setia.
} 
perkawinan khususnya nyentana. Secara umum, pernikahan adat di Bali dibagai menjadi tiga yaitu memadik, ngerorod, dan nyentana. Memadik adalah atas dasar saling cinta dan pernikahan dilakukan di rumah mempelai pria. Ngerorod adalah didasari saing cinta, namun keduanya tidak direstui sehingga melakukan kawin lari atau istilahnya ngerorod. Nyentana adalah didasari saling cinta, namun saat prosesimelamar dilakukan oleh perempuan dan pihak pria wajib mengikuti ketentuan pihak perempuan (Bali Tour Club, 2019)

Nyentana adalah proses perkawinan dengan caraseorang perempuan melamar kepada laki-laki untuk dijadikan suaminya. Motif utama dalam perkawinan nyentana adalah untuk melanjutkan keturunan. Perkawinan nyentana ini juga dianggap unik dan sedikit masyarakat Bali yang melakukannya karena takut denganmitos. Mitos yang beredar di masyarakat Bali bahwa jika seorang laki-laki meninggalkan kewajibannya terhadapleluhur akan mendapat kutukan atau hidupnya akan menemui kesulitan (Ida Padanda Rai Manuaba, Tabanan 2016). Oleh karena itu, banyak masyarakat Bali yang tidak melaksanakan nyentana. Perkawinan nyentana biasanya dilakukan karena saran dari keluarga yang memiliki hubungan kekerabatan yang dekat. Oleh karena itu, beberapa kabupaten yang melaksanakan nyentana ini hanya di Tabanan, Gianyar, dan Singaraja itupun hanya sekitar 1\%. Bahkan di Kabupaten Karangasem sangat ditentang karena dapat merusak garis keturunan.

Sebagian besar masyarakat Bali menentang perkawinan jenis nyentana. Di tengah penolakan tersebut hanya ada salah satu banjar yang melegalkan perkawinan nyentana. Pelegalan nyentana ini karena hukum adat dan agama. Banjar yang melegalkan perkawinan nyentana adadi banjar Kekeran, desa Penatahan, Penebel, Tabanan.Banjar Kekeran menjadi salah satu pelopor yang didukung oleh Lembaga Swadaya Masyarakat dan para aktivis perempuan di Bali (Ni Ketut Sari Adnyani, 2017).

Peristiwa selanjutnya yang melatarbelakangi lahirnya novel Putri adalah tentang tradisi upacara ngaben.Upacara ngaben merupakan upacara kematian dengan carapembakaran jasad yang sudah meninggal. Tradisi yang adasejak zaman dulu dan dilakukan terus-menerus sampai saat ini ditampilkan Putu Wijaya dalam novel. Dalam hal ini kasus yang tampilkan oleh Putu Wijaya ialah kematian seorang Pemangku adat setempat. Pada kasus tersebut seorang perempuan dengan berani menentang keputusan adat tentang pemilihan tingkat upacara 
dengan alasan biaya dan nilai kemurniannya upacara tersebut.

Pada tahun 1960-an pelaksanaan upacara ngaben seringkali dilakukan besar-besaran oleh masyarakat Hindu-Bali sehingga memerlukan biaya yang cukup tinggi dalam sekali pelaksanaan upacara. Upacara ngaben sangat rumit karena memerlukan waktu, biaya dan tenaga khususdan melibatkan banyak orang atau disebut dengan desa-kala-patra. I Wayan Nesa Wisuandha, ${ }^{19}$ menjelaskan bahwa ngaben tak selalu seperti itu. Besar- besaran, berhari-hari, melibatkan ribuan orang, berhura- hura. Ngaben adalah upacara penyempurnaan jasad, mengembalikan unsur-unsur yang membentuk tubuhmanusia ke asalnya. Agama Hindu pun juga membenarkanbahwa, tubuh manusia dibentuk oleh zat yang sama dengan alam semesta, sehingga dikenal dengan istilahbhuwana agung (jagat raya) dan bhuwana alit (unsur dalam tubuh). Jika seseorang telah meninggal, maka telahditinggalkan oleh roh (Sang Atma) dan tubuh tersebuthanyalah

Peristiwa lainya dalam novel Putri adalah dinamikakehidupan sosial budaya yang ada di Puri. Puri adalah sebuah istana atau keratonnya raja Bali. Keberadaan Puri bermulai pada tahun 1343 akibat dari ekspansi kerajaan Majapahit. Runtuhnya kerajaan yang ada di Bali, memunculkan kerajaan baru untuk tetap melestarikan keberadaan Puri Bali. Puri pertama yang terbentuk setelah kerajaan Majapahit adalah Puri Samprangan yang dipimpin oleh Sri Kresna Kepakisan (I Putu Gede Suwitha, 2019). Kemudian disusul oleh kerajaan-kerajaan kecil lainnya.

Keberadaan Puri sangat dijaga karena Puri memilikifungsi penting. Jika dilihat dari aspek sosial, Puri dijadikansebagai tempat tinggal raja atau disebut sebagai istana raja.Dari aspek politik, Puri dijadikan sebagai pusat pemerintaha. ${ }^{20}$ Puri dijadikan sebagai simbol dalam kekuasaan kerajaan. Pada 1580-1665, salahsatu Puri yang menjadi pusat sebagai penguasa tunggal diBali adalah Puri Gelgel dipimpin oleh Dalem Segening. Berdasarkan penelitian I Putu Gede Suwitha 2019, raja Segening juga menguasai hingga Blambangan, Lombok dan Sumbawa. Pada masa pemerintahan raja Segening, tahun 1624 mengadakan perjanjian dengan kerajaan Makassar yaitu tentang pembagian wilayah sebelah Timur. Hasil dari perjanjian tersebut adalah wilayah Sumbawa dikuasai oleh kerajaan Makassar, sedangkan Lombok dikuasai oleh raja Gelgel.

Setelah raja Gelgel digantikan oleh Dalem Dimade pada tahun 1633-1651 terjadilah

\footnotetext{
19 Setia.

${ }^{20}$ Munandar, Istana Dewa Pulau Dewata.
} 
pemberontakan yang dilakukan oleh para petinggi istana Gelgel. Pada tahun 1651, Gelgel dikuasai oleh Ki Agung Maruti dan pada tahun 1686 pasukan bekas punggawa kerajaan Gelgelyang dipimpin oleh Dewa Agung Jambe menyerang Ki Agung Maruti. Setahun setelah penyerangan tersebut, Maruti berhasil dikalahkan tepatnya pada tahun 1687 dantidak berhasil meiminta bantuan dari golongannya yaitu VOC. Setelah peperangan tereebut, Dewa Agung Jambe memindahkan kerajaan Gelgel ke Klungkung. Setelah itu,Bali terpecah ke dalam beberapa kerajaan kecil termasuk kerajaan Klungkung. Peristiwa ini menjadi indikasi yang melatarbelakangi lahirnya novel Putri. Putu Wijaya mengatakan pada awal 1960-an kondisi pemerintahan Baliberubah. Pemerintahan melangsungkan land reform. Kejadian ini seketika melindas para petani dan bangsawan. Banyak yang jatuh bangkrut. Termasuk ayah Putu Wijaya.(Wawancara, 5 Februari 2020).

Hubungan konteks sejarah atau peristiwa yang melatarbelakangi lahirnya novel Putri tidak selalu berkaitan langsung dengan apa yang dialami oleh pengarang. Karya sastra merupakan homologi dari realitaskehidupan yang tidak sama persis terjadi. Oleh karena itu, sejarah atau peristiwa yang melatarbelakangi lahirnya novel Putri dapat disimpulkan dalam beberapa peristiwa. Peristiwa tersebut berkaitan dengan tradisi dan juga budaya masyarakat Bali.

Peristiwa-peristiwa yang ditunjukkan pada novel tersebut merupakan usaha Putu Wijaya sebagai subjekkolektif yang mengasimilasikan lingkungannya ke dalam skema pikiran dan tindakannya. Pada kenyatannya, usaha asimilasi yang dilakukan oleh Putu Wijaya memiliki hambatan-hambatan yang mungkin tidak bisa sesuai dengan pemikiran dan tindakan Putu Wijaya. Seperti yangdikatakan oleh Goldmann ${ }^{21}$ bahwa fakta-fakta yang menjadi respon dari subjek kolektif (Putu Wijaya) tersebut merupakan usaha manusia untuk mencapai keseimbangan yang lebih baik dalam hubungannya dengan dunia sekitarnya.

\section{d. Pandangan Dunia Pengarang}

Pandangan dunia pengarang menurut kaum strukturalisme genetik memiliki proses yang sangatpanjang. Proses yang sangat panjang tersebut disebabkan oleh kenyataan bahwa

\footnotetext{
${ }^{21}$ Faruk, Pengantar Sosiologi Sastra: Dari Strukturalisme Genetik Sampai Post Modernisme Ed. 2 | Fakultas Ilmu Sosial.
} 
pandangan dunia merupakan kesadaran yang-mungkin yang tidak setiap orang dapat memahaminya. Kesadaran yang-mungkin tersebut dilakukan oleh Putu Wijaya dalam menghadapi situasi dankondisi yang ada di sekitarnya pada saat novel diciptakan, sehingga memunculkan sebuah pandangan. Pandangan inimuncul ketika individu berada pada momenmomen krisissehingga diekspresikan melalui sebuah karya.

Putu Wijaya memiliki keprihatinan ketika tradisi gotong-royong yang selama ini dijunjung tinggi oleh masyarakat Bali harus digantikan dengan amplop. Putu Wijaya mengungkapkannya dalam data berikut.

Jangan kita merusak hubungan dengan cara- cara yang dilakukan orang-orang sekarang.Lebih baik kita teruskan memelihara solidaritas gotong-royong dengan kehadiranseperti biasanya. Jangan mengatakannya dengan uang. ${ }^{22}$

Keprihatinan Putu Wijaya dalam melihat tradisi tersebut terjadi karena zaman telah berubah. Sesuatu dinilai karena uang, bukan nilai dan maknanya. Sejak dulumasyarakat Bali sangat menjunjung tinggi tradisi gotong- royong sehingga di Bali banyak kegiatan masyarakat yangmelibatkan orang. Seperti dalam pelaksanaan upacara-upacara adat. Pada pelaksanaanya melibatkan banyak orang mulai dari sebelum, saat, dan sesudah pelaksanaan.

Pelaksanaan upacara ngaben di Bali sering kali rumit dan timbul masalah (Kabayantini, 2013:7). Hal ini dikarenakan karena masyarakat sudah terjebak oleh tradisiyang berlaku sejak dulu dan dilaksanakan secara terus- menerus dengan biaya yang tinggi dan mengabaikan kemampuan pribadi pelaksana. Ketut (2018:9) mengatakan dalam bukunya tentang ngaben sebagai berikut.

"Upacara ngaben merupakan salah satubentuk pelaksanaan upacara pitra yadnya yaitu penyelenggaraan upacara setelah kematian yang hendaknya harus dilaksanakan oleh umat Hindu, karena upacara ini merupakan salah satu usaha untuk membayar hutang kepada paraleluhur, yang memiliki tujuan untuk melepaskan atma dari ikatan stula sariraatau unsur panca maha bhuta, upacara ngaben wajib dilaksanakan sentana, yaitu keturunan dari yang meninggal, sebagai bentuk penghormatan kepada orang tua. Upacara ngaben sukanlah suatu pemborosan, karena upacara ini adalah yadnya yang dilandasi hati yang

\footnotetext{
${ }^{22}$ Wijaya, Putri.
} 
tulus ikhlas, sebagai usaha membayar hutang kepada orang tua atau leluhur.”

Putu Wijaya juga mengutarakan pandangannya tentang kehidupan di Puri Bali. Putu Wijaya menunjukkan betapa berharganya Puri bagi kaum bangsawan. Puri menjadi pemilik kedudukan tertinggi di dalam tatanan sosial, Puri juga menjadi panutan bagi masyarakat. Banyak yang berusaha untuk menjadi bagian Puri. Bahkan tidak sedikit yang rela membeli kasta agar bisa dianggap sebagaibagian Puri.

Putu Wijaya merasakan kesenjangan sosial antara orang-orang yang hidup di dalam Puri dan di luar Puri. Kesenjangan yang paling terlihat adalah kasta. Seseorang yang lahir di Puri, otomatis akan mendapatkan kasta dari orang tuanya dan menerima segala hak dan kewajiban di dalam Puri. Hidup di Puri dengan segala isinya bergelimang harta, kekuasaan, dan juga status sosial tidakmembuat seseorang bisa hidup bebas. Tidak sedikit orangyang ingin membebaskan dari segala tradisi yang ada di Puri. Ngurah Wikan contoh gambaran yang ada di dalam novel, sedangkan di dunia nyata adalah Putu Wijaya sendiri. Ngurah mencoba melepaskan diri dari Puri, ia lantas pergi ke Amerika. Akan tetapi kepergiannya tidak bisa lepas begitu saja, banyak beban yang harus ditanggungnya. Ngurah Wikan harus siap melepaskan kekuasaanya serta lepas dari adat. Selain itu, ia juga harussiap menerima segala cibiran dari orang-orang yang tinggal di Puri, walaupun mereka sendiri sebenarnya inginjuga melepaskan diri dari Puri. Harus ada keberanian seperti Wikan, walaupun dicap sebagai pengecut karena melepas tanggung jawab di Puri. Selain itu keinginan Ngurah Wikan untuk melepaskan diri dari Puri, dipaparkan dalam data berikut ini. Perbedaan kasta di Bali juga berpengaruh dengan adat perkawinan. Pandangan Putu Wijaya tentang kasta sebagai berikut.

"Perbedaan kasta yang masih menjadikendala dalam pernikahan, tidak hanya diberi pembenaran oleh adatdengan kawin lari, tapi kini juga sudah diterobos dengan sangat berani. Lelaki dari kasta biasa tak perlu lagi harus melarikan kekasih yang berasal dari keluarga biru, karena keluarga bangsawan kini sudah bisa menerima bahwakedudukan dalam masyarakat adalahkasta baru. ${ }^{23}$

Perbedaan kasta di Bali juga menjadi tradisi yangmasih dilakukan sampai sekarang

${ }^{23}$ Wijaya. 
terutama pada Hindu- Bali. Ketika seorang perempuan berkasta rendah menikahdengan lelaki dari kasta yang lebih tinggi, maka bisamenjadi kebanggaan tersendiri bagi perempuan karena naik kasta. Tetapi pihak perempuan juga harus siap menerima konsekuensinya yaitu diperlakukan tidak sejajar. Sebagai contohnya yaitu ketika pelaksanaan pernikahan, banten perempuan diletakkan di bawah. Contoh lainnya yaitu pihak perempuan harus siap melayani ipar dan keluarga lainnya. Peristiwa ini tentu merugikan perempuan, tetapi seiring perkembangan zaman, peristiwa itu sudah jarang terjadi.

Pandangan-pandangan tersebut seolahmendiskriminasi sosok perempuan karena dianggap tidak memiliki hak dan kekuasaan atas dirinya. Oleh karena itu,selama ini, di Bali yang sering dilakukan adalah prosesi ngerorod (laki-laki melamar perempuan). Perempuan harus rela menunggu di rumah dan ditugaskan di dapur. Kedudukan laki-laki dianggap lebih tinggi daripada perempuan. Padahal peranan perempuan juga sangat besar dalam kehidupan baik itu keluarga hingga masyarakat. Bahkan perempuan memiliki keunggulan tersendiri yang disebut-sebut sebagai seseorang yang multi tasking.Artinya, selain memiliki peran di segala bidang, perempuan juga bisa menjadi apa saja dan melakukan apa saja yang tidak bisa dilakukan oleh kaum laki-laki. Penelitian yang dilakukan oleh Lita Gustiana dkk (2018), perempuan memiliki peran sebagai ibu, istri (pendamping hidup), pribadi dalam masyarakat, dan juga pendidik. Begitu kompleks peran yang dimiliki oleh perempuan. Mulai dari melahirkan, membesarkan, dan mendidiknya hingga dewasa.

Kenyataan bahwa perempuan memegang peranan penting di dalam kehidupan seperti penelitian yang dilakukan oleh Slamet Widodo ${ }^{24}$ dalam penelitian Analisis Peran Perempuan Usaha Tani Tembakau bahwa perempuan dapat melakukan aktivitas reproduktif sekaligus produktif. Dalam hal ini kegiatan reproduktif yang dimaksudkan adalah kegiatan yang berhubungan dengan pekerjaan rumah, mengurus anak, suami dan sebagainya. Perempuan juga bisa melakukan aktivitas produktif yang berhubungan dengan pengelolaan keuangan. Perempuan dilibatkan dalam pengelolaan keuangan karena stereotip bahwa perempuan lebih bisa mengatur perihal keuangan daripada laki-laki. Tidak sebanding dengan dilakukan oleh perempuan, ketika sudah berbicara mengenai adat dan budaya, maka dominasi laki-laki kembali hadir. Ketika sudah dihadapkan dengan pengambilan keputusan, maka laki-laki masih

\footnotetext{
${ }^{24}$ Slamet Widodo, “Analisis Peran Perempuan Dalam Usahatani Tembakau," Fakultas Pertanian, Universitas Trunojoyo Madura 6, no. 2 (December 2009): 148-53.
} 
mendominasi. Perbedaan pengambilan keputusan tersebutyaitu $81 \%$ laki-laki, $6 \%$ perempuan. Jika dilihat angkanya, sangat berbeda jauh. Sama halnya dengan keputusan nyentana yang dilakukan oleh tokoh Putri. Perbedaan suara yang sangat signifikan, membuatnya menjadi kaum minoritas yang belum bisa mengubah stereotip tersebut.

Penelitian peranan perempuan juga dilakukan oleh ${ }^{25}$ tentang kesetaraan gender dalam pandangan Islam yang dilihat dari aspek penciptaan di dalam kitab Al-qur'an menyatakan bahwa hawa (perempuan) diciptakan dari tulang rusuk adam (laki-laki).Perempuan tidak memiliki derajat yang lebih rendah dibandingkan laki-laki, tetapi sebagai mitra yang saling bergantung dan membutuhkan satu sama lain. Kemudian, dalam aspek kesetaraan gender terutama dalam aspek kepemimpinan Sri Fadilah juga mengatakan, "Secara fungsional, memang benar suami adalah pemimpin rumahtangga karena Allah memberikan kelebihan secara kodratikepada kaum laki-laki, tetapi dalam kondisi tertentu, secara ekonomi, istri dapat berperan sebagai pemimpin dalam rumah tangga."

Tidak dapat dipungkiri bahwa perkembangan zaman juga membawa perubahan sosial masyarakat yang terutama berawal dari lembaga masyarakat dalam lingkup keluarga. Menurut Sumiyatiningsih" ${ }^{26}$, "Keluarga menjadi dasar lembaga kemasyarakatan memiliki peran penting dalam pergeseran peran suami-istri (laki/perempuan).” Keluarga menjadi benteng untuk masa depan anak-anaknya. Artinya, ketika di dalam keluarga sudah diterapkan budaya patriarki tentang dominasi laki- laki, maka anak-anak akan mengikuti perilaku yang sudahmembudaya. Oleh sebab itu, sejak dini harus diberikan perhatian khusus. Simyatiningsih (2010) menyebutnya dengan "Gereja kecil”. Artinya, keluarga tidak salah paham dalam melihat patriarki untuk memonopoli perempuan melalui aturan yang ada di keluarga. Menurutnya, dalam biblis juga menyatakan bahwa manusia satu dengan yang lainnya hidup sebagai mitra, bukan memonopoli antara yang satu dengan yang lain.

Berdasarkan penjelasan di atas, kedudukan antara laki-laki maupun perempuan

\footnotetext{
${ }^{25}$ Sri Fadilah, "Kesetaraan Gender: Fenomena Pergeseran Peran Ekonomi Wanita Dari Tulang Rusuk Menjadi Tulang Punggung," Mitra Gender (Jurnal Gender Dan Anak) 1, no. 1 (May 2, 2018): 18-26, https://doi.org/10.29313/.v1i1.3732.

${ }^{26}$ Dien Sumiyatiningsih, "Pergeseran Peran Laki-Laki Dan Perempuan Dalam Kajian Feminis | Waskita" 2016-02-12, no. Vol 4 No 2 (2013), accessed July 30, 2021, https://ejournal.uksw.edu/waskita/article/view/178.
} 
sebenarnya bisa dikatakan sama. Kemitrasejajaran yang harmonis antara pria dan wanita adalah suatu kondisi hubungan kedudukan dan peranan yang dinamis. Antara pria dengan wanita mempunyai persamaan kedudukan, hak, kewajiban, dan kesempatan, baik dalam kehidupan berkeluarga, bermasyarakat, berbangsa dan bernegara maupun dalam kegiatan pembangunan segala bidang (Menteri NegaraPeranan Wanita, 1998).

Putu Wijaya juga tidak hanya memandang kedudukan antara perempuan dan laki-laki di zaman yangmodern, tetapi juga melihat ke belakang dengan melihat tokoh pewayangan yaitu Drupadi dan Dewi Arimbi sebagai lambang kekuatan. Sosok Drupadi yang dijadikan lambang kekuatan bagi kaum pria karena Pandawa bergantung padanya. Dewi Arimbi sebagai sosok yang dipandang sebagai sosok perempuan yang memiliki nilai luhur dari rohaninya bukan fisiknya. Berikut pandangan Putu Wijaya melalui tokoh ciptaanya.

"Wanita bukan makhluk lemah, tetapi makhluk yang kuat," lanjut orang tua itu. "Dewi Arimbi adalah raksasa yang perkasa,tetapi keperkasaannya bukan keperkasaan wadag, melainkan keperkasaan rohani. Di dalam riwayat hidup putra kedua Pandawa ini, Bima dikenal sebagai lambang kekasaran dan kejujuran..."27

Dengan demikian, pandangan Putu Wijaya tentang perempuan ialah sosok yang mampu memancarkan kekuatan bagi orang lain terutama bagi laki-laki. Perempuan bukan manusia yang lemah, tetapi sebagaisumber kekuatan. Sosok yang dicontohkan oleh Putu Wijaya ialah Drupadi yang tidak hanya cantik, tetapi jugaterkenal dengan kesetiaanya serta tahan banting. Sosok yang kedua digambarkan melalui Dewi Arimbi. Sosok yang memiliki fisik tidak bagus, tetapi mampumemancarkan keperkasaan dan rohani yang baik.

Berdasarkan pemaparan tersebut, dalam novel Putri, Putu Wijaya berpandangan bahwa tradisi dapat tumbuh, berkembang bersentuhan baik dengan perkembangan zaman untuk membangun citra, karakter, dan kepribadian bangsa. Putu Wijaya melalui Bali sebagai salah satu tradisi tersebut, dalam prosesnya bersentuhan dengan modernisasi, alam kemerdekaan, perkembangan sosial-politik, dan ekonomi seharusnya beriringan dan sejajar menuju ke arah yang lebih baik.

\footnotetext{
${ }^{27}$ Wijaya, Putri.
} 


\section{Kesimpulan}

Struktur dalam novel Putri karya Putu Wijaya dapat disimpulkan bahwa setiap problematika antara tokohdengan tokoh maupun dengan objek di sekitar,dilatarbelakangi oleh tradisi. Problematika yang dialami oleh tokoh-tokoh dalam novel Putri, adalah gambaran masyarakat dalam menghadapi tradisi. Berdasarkan problematika-problematika tersebut dapat terlihat realita kehidupan masyarakat tradisi yang ada di Indonesia khususnya Bali karena tema yang diangkat dalam novel Putri adalah tradisi Indonesia. Tokoh-tokoh yang ada padanovel juga memggambarkan masyarakat tradisi.

Pandangan Putu Wijaya yang terefleksi dalam novel Putri merupakan gagasan aspirasi maupun perasaanPutu Wijaya terhadap tradisi yang ada di Bali. PandanganPutu Wijaya dalam novel Putri bersentuhan dengan tradisiyang tumbuh dan berkembang seiring perkembangan zaman. Putu Wijaya melalui perempuan Bali berhasil melakukan perubahan pandangan masyarakat terhadap tradisi dan perempuan dalam prosesnya bersentuhan dengan modernisasi.

\section{Saran}

Berdasarkan pembahasan hasil penelitian dankesimpulan yang terkait dengan pandangan dunia pengarang dalam novel Putri karya Putu Wijaya, penulis memiliki saran yang perlu ditindaklanjuti baik untuk pembaca, pengembangan penelitian, maupun peneliti selanjutnya yang berhubungan dengan kajianstrukturalisme genetik. Berikut saran yang ditujukan bagi pembaca, mahasiswa dan peneliti selanjutnya.

1) Bagi pembaca, diharapkan agar dapat lebih memahamimakna dan memanfaatkan pesan yang terkandung di dalam novel Putri karya Putu Wijaya.

2) Bagi mahasiswa, hasil penelitian dapat dijadikan bahandiskusi mata kuliah Sosiologi Sastra.

3) Bagi peneliti selanjutnya, agar dapat menemukan topik-topik menarik lainnya yang bisa dikaji lebih dalam dengan menggunakan kajian teori yang berbedadari novel Putri, atau bisa juga novel lain yang bisa dikaji dengan teori ini.

\section{Daftar Pustaka}


Fadilah, Sri. "Kesetaraan Gender: Fenomena Pergeseran Peran Ekonomi Wanita Dari Tulang Rusuk Menjadi Tulang Punggung." Mitra Gender (Jurnal Gender Dan Anak) 1, no. 1 (May 2, 2018): 18-26. https://doi.org/10.29313/.v1i1.3732.

Faruk. Pengantar Sosiologi Sastra: Dari Strukturalisme Genetik Sampai Post Modernisme Ed. 2 | Fakultas Ilmu Sosial. Yogyakarta: Pustaka Pelajar, 2012. http://fis.uny.ac.id/perpustakaan/koleksibuku/pengantar-sosiologi-sastra-dari-strukturalisme-genetik-sampai-post.

Munandar, Agus Aris. Istana Dewa Pulau Dewata : Makna Puri Bali Abad Ke-14 - 19. Komunitas Bambu, 2005.

Setia, Putu. Bali Menggugat. Kepustakaan Populer Gramedia, 2014.

Sudarsana, I. Ketut. "NGABEN WARGA DADYA ARYA KUBONTUBUH TIRTHA SARI DESA ULAKAN KARANGASEM (Perspektif Pendidikan Agama Hindu)." Jayapangus Press Books, February 15, 2018, i-129.

Sumiyatiningsih, Dien. "Pergeseran Peran Laki-Laki Dan Perempuan Dalam Kajian Feminis | Waskita” 2016-02-12, no. Vol 4 No 2 (2013). Accessed July 30, 2021. https://ejournal.uksw.edu/waskita/article/view/178.

Widodo, Slamet. "Analisis Peran Perempuan Dalam Usahatani Tembakau.” Fakultas Pertanian, Universitas Trunojoyo Madura 6, no. 2 (December 2009): 148-53.

Wijaya, Putu. Putri. Grafiti, 2004. 